\title{
MANAGEMENT OF RECEIVABLES ON THE EXAMPLE OF BUSINESS ENTITIES FROM THE PLOCK SUBREGION
}

\author{
Barbara FELIC, Magdalena GRABOWSKA, Agnieszka KRZĘTOWSKA, \\ Marlena PIEKUT, Renata WALCZAK \\ College for Economic and Social Sciences, Warsaw University of Technology, Płock, Poland \\ e-mail: \{bfelic, mgrabowska, krzetowska, piekutm,rpwalcza\}@pw.plock.pl
}

\begin{abstract}
The article presents a problem and differences of financial liquidity and profitability. The survey of financial liquidity and profitability, underwritten by the College of Economics and Social Sciences of Warsaw University of Technology, was conducted on Płock Subregion enterprises. The survey concerned cash flow management, receivables controlling, trade credits, different payments and receivables. The results of the conducted survey indicate that the majority of companies from the subregion of Płock suffer several problems and despite a wide range of possibilities of using different tools for the management of receivables, the respondents do not use them efficiently. The survey has shown that most of them applies only the most popular, simplest and cheapest solutions, but, consequently the least efficient.
\end{abstract}

Key words: financial liquidity, profitability, subregion of Płock.

One must choose in life between making money and spending it.

There's no time to do both.

Eduard Bourdet

\section{Introduction}

Proper functioning of business entities in a market economy is a determinant of a variety of both internal and external factors. Modern market economy is based on entities operating on the market, the effects of which are mutual settlements of accounts of the participants of the economic exchange. Together with deferred payments appear accounts receivable.

One of the fundamental areas responsible for the security of an entity is the size of the sales that constitutes a source of monetary proceeds. Today, however, the mere sales are insufficient.

Efficient and successful management of receivables is one of the most important tasks that a business enterprise must realise. Beside from actions related to receiving a trade credit, they should also be related to the price discount policy applied by the company and the extent of utilisation of the tools for the management of receivables. We need to remember that even a shortterm cash deficit may have a negative impact on the existence and position of the entity on the market. All financial decisions should focus on the efficiency of the cash flow and its effective utilisation. The need to maintain cash flow, conditioned by the level of financial resources and the possibilities of their obtain- ment, has become a very significant issue in the Polish economy.

The aim of this study is to analysis the utilisation of the available tools for the management of receivables on the example of the Płock subregion with particular focus on the scale of overdue payments, reasons for their occurrence and methods of prevention.

\section{$2 \quad$ Receivables vs. trade credit}

A receivable, because of the conducted economic activity, is a debtor's responsibility towards the creditor that should be satisfied in a specified term and amount. A receivable is most often perceived as a right of an entity to receive money from another entity. This however has to be analysed from the financial, legal and accounting points of view (see Fig. 1) ${ }^{1}$.

Accounts receivable is an important component of the entity's balance sheet and its control should be an important element of the entity's operation strategy. A trade credit, the result of which is a receivable, is necessary if we want to conduct economic activity. It has impact on the sales growth and, consequently, ensures company's development.

\footnotetext{
${ }^{1}$ K. Kreczmańska-Gigol - Windykacja należności. Difin, Warsaw 2011, p. 25.
} 


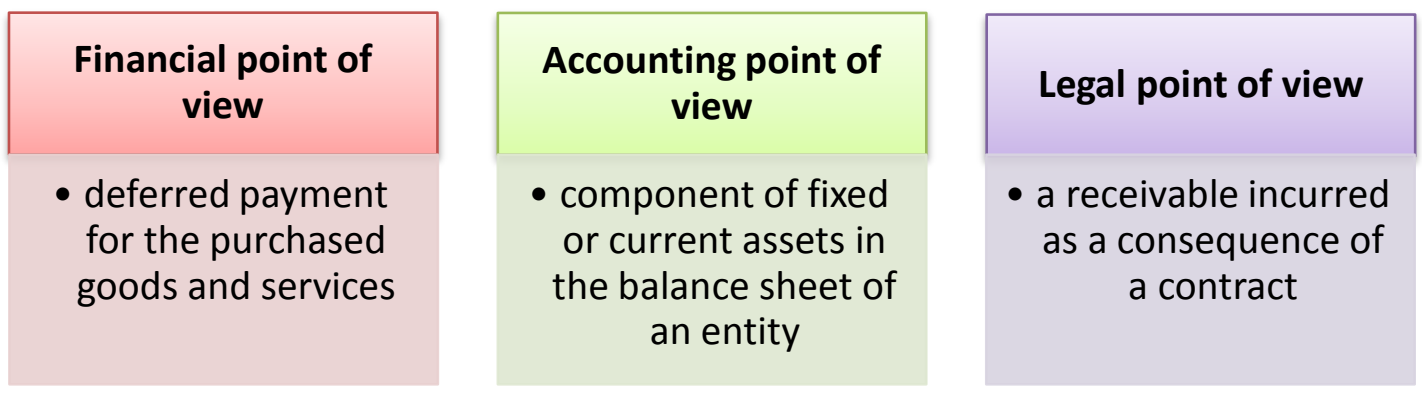

Figure 1. Points of view on the receivables (source: own research)

The control of the receivables is tightly related to the strategy of cash flow that determines the possibility of taking a credit by the company, its' terms and conditions as well as the possibility of crediting the recipients of goods and services. To exist on the market, an entrepreneur must carefully control his cash flow, which is part of the management of receivables. Receivables should undergo a constant and regular evaluation. The control of the receivables depends on many factors that condition an efficient operation of business entities. The consequence of a surge in the level of receivables is an increase in the demand for net working capital and a growth in the risk of overdue receivables and, hence difficulties with timely payments.

Cash flow management is a decision-making process, whose effect is incoming and outgoing cash in a business entity. The success or failure of an enterprise depends on the efficiency of this area, as the company's solvency is a condition for its presence on the market. Insufficient liquidity will mean serious consequences for the entity and consequently may lead to bankruptcy.

On the other hand, however, in the end, the existence of a business entity is impossible without appropriate profitability $^{2}$. The profit constitutes a source of the company's growth of assets and capital, thus adding to the value of the company and securing benefits for the owners. Yet, today, the mere profitability is not tantamount to having monetary means allowing timely payments.

Profit is a result of the company's achievements and is a source of financing of the business development, but it is the liquidity that determines the real possibilities of financing. It also constitutes a basis for future profitability. Maintaining financial liquidity is treated as

\footnotetext{
${ }^{2}$ Sierpińska M., Wędzki D. - Zarządzanie ptynnościq finansowa w przedsiębiorstwie. PWN, Warsaw 2005, p. 7.
}

a strict by-condition for profitability ${ }^{3}$, whose failure to meet results in the elimination of a player from the market game. The struggle for profitability must be realised securing the financial liquidity. Profitability does not guarantee liquidity and the lack of profitability does not have to mean problems with timely payments.

Maintaining liquidity is a short-term objective of the company activity, so that in the end the owners equity and the value of the enterprise could be multiplied ${ }^{4}$ and constitute secure foundations for development.

The essence of liquidity is expressed in the words of Wojciech Topolnicki in 2009, vice-president for development and finance of Polska Grupa Energetyczna (Polish Energy Group) during a debate by 'Rzeczpospolita': 'Company financing in the time of crisis" : '(...) I agree that today it is not so much the profit margin that is important but access to cash, financing. If we don't have liquidity, you go bust. It does not matter that we have a great portfolio and many clients waiting for our products. If you do not have cash these days you must go bankrupt.'

Today the sales with a deferred payment are a natural thing, resulting from both the client expectations and standards in the business. Trade credit is a source of financing the business activity. It facilitates securing new clients and allows maintaining collaboration with the existing ones.

\footnotetext{
${ }^{3}$ Waśniewski T., W. Skoczylas W. - Teoria i praktyka analizy finansowej przedsiębiorstwa [in] Fundacja Rozwoju Rachunkowości w Polsce, Warsaw 2002, p. 431.

${ }^{4}$ Sierpińska M., Wędzki D. - Zarzqdzanie plynnościq ..., op. cit., p. 11.

${ }^{5}$ Fandrejewska A., Krześniak M. - Jak rozruszać kredyt [in] Rzeczpospolita, 1.07.2009, pp. B7-B8.
} 


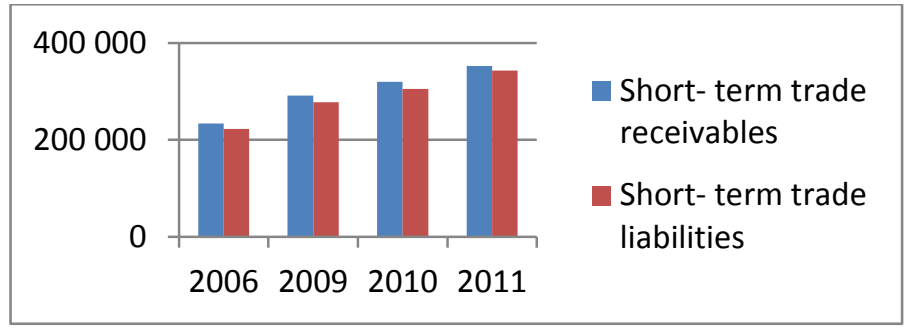

\section{Graph 1. Trade receivables and liabilities in Polish non-financial enterprises in millions of plz (source: Own source based on Balance Sheet Financial Results of Business Entities by (GUS, 2006-2011)}

This also means certain inconveniences for the seller. It brings a variety of unknowns, the most important of which is the risk of overdue payments, which may increase the costs of financing and management of receivables. Deferred payment is very often an alternative to bank loans whose approval is dependent upon a positive verification based on bank procedures.

Relevant literature distinguishes two patterns related to a trade credit. In the financial aspect, it is a source of financing that is an alternative to a bank loan. The conducted research confirms the increasing role of a trade credit in the situation of limited access to external financing ${ }^{6}$. The supplier, owing to an established collaboration with a business partner, can monitor changes in his financial situation, which gives him an information advantage over a financial middleman ${ }^{7}$.

According to a market pattern, trade credit is a resultant of the number of transactions and size of the sales. It allows a reduction of the transaction costs and costs related to the maintenance of the finished products. It also allows the application of flexible pricing policies and improves cash flow management.

The phenomenon of a substitution of trade credit for a bank loan is more frequent in small business entities, irrespective of the business sector of operation ${ }^{8}$.

Receivables play an important role in supporting the sales. Their level is a resultant of the policy of recipient crediting by the entity, whose aim is to maximise the sales at an acceptable level of risk. The significance of receivables for the Polish economy is shown in Graph 1.

\footnotetext{
${ }^{6}$ Por. Petersen M., Rajan R. - Trade credit, theories and evidence [in] Review of financial Studies 10(3), 1997, p. 661.

${ }^{7}$ Wasilewski W. - A Total Risk Assessment in an Enterprise [in] Foundations of Management, Vol. 04, No. 02(8), 2012.

${ }^{8}$ Marzec J., Pawłowska M. - Substytucja miedzy kredytem kupieckim i bankowym $w$ polskich przedsiębiorstwach [in] Bank i Kredyt, 43(6), 2012, p.45
}

The analysis of data provided by Główny Urząd Statystyczny (National Office for Statistics) indicates a constant growth in the level of receivables being a result of trade credits. In 2011 these increased by $10 \%$ as compared to the previous year but in comparison to 2006 this was already a 50\% growth. The analysis of the structure of assets of Polish enterprises based on the data from 2011 indicates a high share of short-term trade receivables in the balance sheet. They constituted $15 \%$ of the assets. Their share in the current assets already amounted to $36 \%$.

Trade credit is currently treated as an important element of the trade policy, determining the level of market competitiveness.

The competitive potential depends on many factors ${ }^{9}$ such as: market share, cost efficiency, image, technological skills and technological level, level of organisation and management, profitability and financial policy of an enterprise. In order to ensure the above, the following are important: reputation, time of completion of an order, accessibility to materials, flexibility and adaptability to the client requirements, knowledge and competence of the employees, innovativeness, information resources and many other. The approval of a credit (that may become a trade credit) frequently becomes a competitive advantage ${ }^{10}$. Trade credit is perceived as an element of the competition frequently used by the recipients whose bank creditworthiness is insufficient or who are deterred by the complexity of the bank procedures or the required security.

The length of the payment deferral and the relevant terms and conditions, particularly in small businesses, may constitute a tool modifying the demand resulting in an increase in the sales and reinforcing of the posi-

\footnotetext{
${ }^{9}$ Gierszewska G., Romanowska M. - Analiza strategiczna przedsiębiorstwa. PWE, Warsaw 2009, p. 129.

${ }^{10}$ Bień W. - Problemy efektywnej sprzedaży na kredyt [in] Zarządzanie majątkiem obrotowym $\mathrm{w}$ przedsiębiorstwie, red. J. Grzywacz, SGH, Warsaw 2006, p. 77.
} 
tion on the market. This tool is of particular importance for entities in the initial phase of development or those that are seeking markets for new products or services. Large enterprises of established market position frequently impose on clients short and only slightly negotiable deferrals of payment ${ }^{11}$.

We need to note that the decision on approving a trade credit cannot be made independently without consultation. Its terms depend on the decision taken in other areas and the consequences are interrelated. It does happen sometimes that local objectives of individual departments are in opposition to the global tasks in other areas of activity or even to the strategic objective of the company. The supplies departments aim at maintaining a high level of goods in stock in order to ensure the continuity of production, not minding the related costs. The key to success and maintaining equilibrium is the postulate stressed in logistics related to a complex judgement of the activity and evaluation of the purposefulness of individual actions from the point of view of the main objective.

When we decide to give our clients a trade credit, we need to strictly adhere to the adopted strategy related to the compromise between the acceptable risk and the plans to boost the sales. We may distinguish a conservative strategy of the lowest risk level and the lowest sales growth quotas, moderate strategy and aggressive strategy that assumes a boost in the sales level but also accepts the highest level of risk. In order to protect the business against the risk of losing financial liquidity, we must not let the amount of receivables exceed the sources of refinancing of the liabilities of his debtors available to the supplier ${ }^{12}$.

There are measurable and immeasurable benefits that are suggestive of creating receivables, thus allowing deferred payments. This allows an increase of the sales by securing new clients. This may result in a more effective use of the production capacity, which directly translates into the cost level. Offering a deferred payment to clients also allows collaboration with clients having a temporary cash deficit. This also means liquidation of stock, which again translates to measurable financial benefits related to the reduction of the costs of stock keeping, its wear or loss of value.

\footnotetext{
${ }^{11}$ Seretny M., Seretny A. - Sustainable marketing - a new era in the responsible marketing development [in] Foundations of Management, Vol. 04, No. 02(8), 2012.

${ }^{12}$ W. Bień, - Problemy ..., op. cit., s. 85.
}

\section{Overdue Receivables}

The management of receivables is a wider term than the receivables themselves. This pertains to actions related to the trade policy towards the recipients, the principles of approving of a trade credit, its size and limits or the amount of possible discounts. It covers processes that influence the level of receivables but it goes a bit further and should not be identified with the mere control or monitoring of receivables. As the payment morality of companies deteriorates, payment backlogs intensify and management of receivables becomes increasingly important. The main objective of the management of receivables is the attempt to reduce the unsettled payment, maintain continuity in the cash flow and maintain positive relations with the clients.

The efficiency in the management of receivables is tightly correlated with the strategy of financing of the contractors and it can be measured with the index of the share of overdue receivables being the consequence of approved trade credits.

Untimely settlement of accounts is a serious problem for the managers of receivables. This is confirmed by periodical surveys by BIG Infomonitor ${ }^{13}$, where $80 \%$ of the companies admitted that untimely payments were a serious obstacle in conducting business operations. It is noteworthy however that we are observing an improvement and within the last three months, the number of companies treating untimely payments as incidental grew by $3 \%$.

Besides, the last report confirmed that $64 \%$ of the companies positively evaluated their contractors in terms of their financial liquidity. For over a year now the group of companies receiving $90 \%$ of their payments without any delay has been growing. In March, the percentage of such companies was $16 \%$ and today the group has grown to $21 \%$. There is still, however, a group of entities confirming the existence of overdue receivables. From the group of companies $46 \%$ of the respondents declared delayed payments exceeding the amount of plz 100.000 while three months earlier this share was $13 \%$ lower.

\footnotetext{
${ }^{13}$ The report of BIG (Consumer Reporting Agency) - The index of security of business transactions [in] BIG InfomMonitor. Warsaw, September 2013, p. 9.
} 


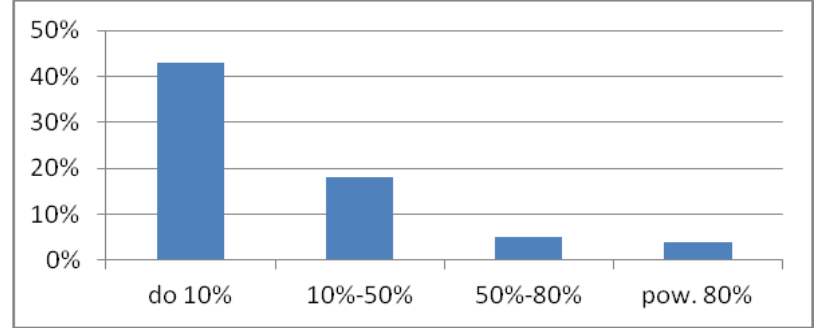

Graph 2. Percentage share of overdue receivables (source: own research)

Table 1. Percentage of overdue payments (source: based on own studies)

\begin{tabular}{|c|c|}
\hline $\begin{array}{c}\text { Period of overdue payments } \\
\text { of Polish enterprises }\end{array}$ & $\begin{array}{c}\text { Percentage of overdue payments } \\
\text { of Polish enterprises }\end{array}$ \\
\hline Up to 1 month & $41 \%$ \\
\hline From 1 to 3 months & $23 \%$ \\
\hline More than 3 months & $5 \%$ \\
\hline
\end{tabular}

This fact is also confirmed by the surveys performed on a group of entities from the subregion of Płock. The majority of companies from the subregion of Płock ${ }^{14}$ declared deferral of payment for their contractors on the level not exceeding 45 days. Over $60 \%$ of the companies estimated that up to $50 \%$ of their receivables had not been settled in time (Graph 2). Timely payments were declared by over $30 \%$ of the respondents.

In the group of all the respondents $43 \%$ estimated that the share of untimely payments did not exceed $10 \%$ of the total receivables. The majority of the respondents confirmed issues with timely payments. Every third invoice was paid with a delay of up to one month and for another $20 \%$ the delay was from one to three months.

It is also noteworthy that despite a high percentage of the indications of untimely payments half of the entities declared timely payments of their own liabilities to the suppliers. If the payment reliability level were as good as the respondents declared the payment backlogs would not be such frequently indicated obstacle in the economic operations.

For a group of $41 \%$ entities the delay in the received payments did not exceed one month. For $23 \%$ of the

\footnotetext{
${ }^{14}$ Survey conducted in the beginning of 2013 on a group of 95 companies from Płock, the Płocki Poviat and the surrounding Poviats.
}

companies the overdue receivables were collected after at least one month from the due date, but the delay did not exceed three months. A detailed distribution of untimely payments has been shown in Table 1 .

The results of the conducted survey indicate that the prevailing receivables were those 3 months in arrears while the share of receivables more than 3 months in arrears did not exceed 5\%.

Delayed payments have become a common thing recently. The greatest risk came not from the fact of their mere presence but the fact that these actions were intended. The entrepreneurs intentionally took advantage of the rare instances of charging default interest and applied the policy of payment delays. Instances of warranty claims have also been recorded with a view to delaying the payment. This trend was particularly commonplace in the building sector where the long investment process and the engagement of many entities facilitated the extension of the times when the payments were made.

The analysis of responses related to the actions taken if arrears in payment occurred indicates several main and preferred solutions (Graph 3). These were: cost reduction, extension of the payment time of own liabilities to own suppliers and seeking new sources of financing. The respondents often considered changing the realised pricing policy. The authors also observed that debt recovery was gaining in significance. 


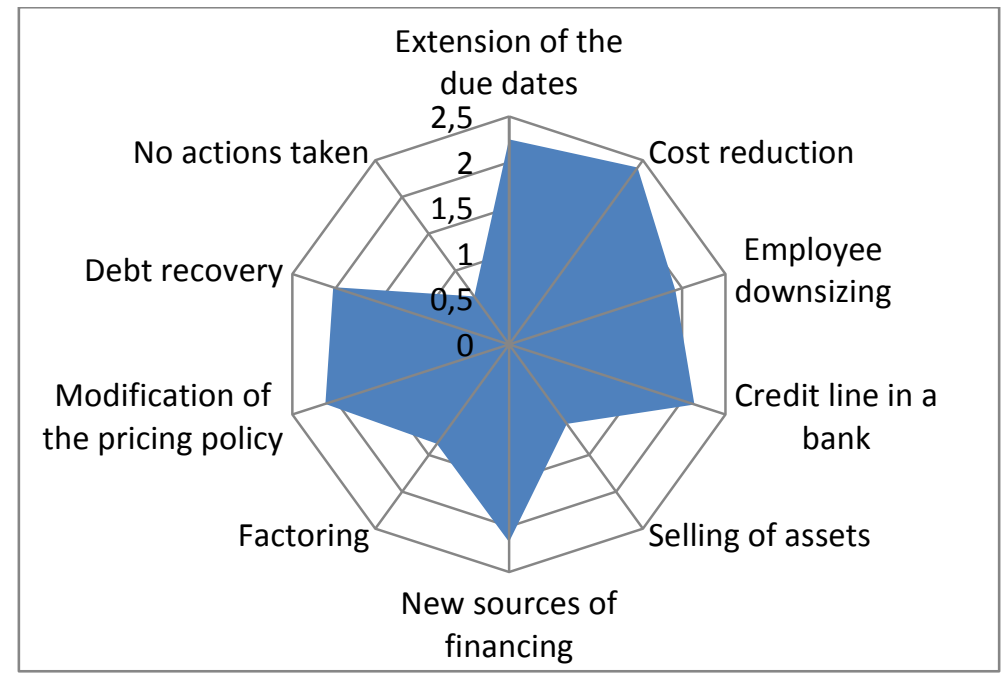

Graph 3. Actions taken if arrears occurred (source: based on own research)

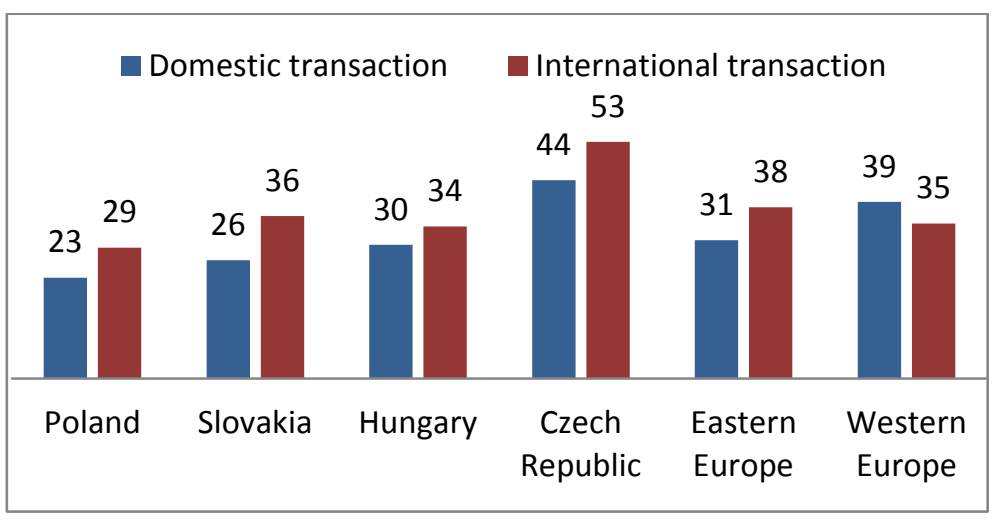

Graph 4.: Average duration of given trade credits in days

(source: Own studies based on: Atradius Payment Practices Barometr, June 2012, Atradius, p. 11)

\section{The problem of payment backlogs}

Another risk when conducting economic activity is the problem of payment backlogs. A helpful tool when collecting overdue payments may be continuous monitoring of the receivables thus improving the efficiency of debt recovery. If we consider proactive behaviour as a tool, the entrepreneurs could focus their attention on checking the credibility of their present or future contractors. ${ }^{15}$ Checking the clients credibility prior to signing a contract would eliminate the risk of entering into collaboration with an unreliable payer or would enable taking precautions and adapt the security of a receivable ascribed to a given transaction, thus improving the safety of the deal.

\footnotetext{
${ }^{15}$ Rzeszutek E. - Holding groups: a safe corporate structure at the time of recession [in] Foundations of Management, Vol. 04, No 02(8), 2012.
}

The problem is not confined to the Polish economy - it reaches much farther.

The problem of overdue receivables for goods and services is observed in the majority of countries. The list of average number of days of payment of receivables offered to clients in 2012, in selected countries has been shown in Graph 4.

A disadvantageous phenomenon however was the change in the structure of the receivables in terms of the actual number of days prior to payment. An increase in the share of the longest payment delay was over 90 days. This may mean that a part of the delayed payments will most likely become overdue payments or even bad debts. For an entity, it means additional costs of debt recovery or legal action and sometimes it is simply treating the entire overdue payment as financial loss. 
Table 2. Delayed payments

(source: own studies based on: Atradius Payment Practices Barometr, June 2012, Atradius, p. 16)

\begin{tabular}{|c|l|c|c|c|}
\hline & & $\begin{array}{c}\text { Up to 30 } \\
\text { days }\end{array}$ & From 30 to 90 days & $\begin{array}{c}\text { In excess of 90 } \\
\text { days }\end{array}$ \\
\hline \multirow{2}{*}{ Poland } & Domestic transactions & $71.7 \%$ & $23.0 \%$ & $5.3 \%$ \\
\cline { 2 - 5 } & International transactions & $70.6 \%$ & $22.2 \%$ & $7.2 \%$ \\
\hline \multirow{2}{*}{ Slovakia } & Domestic transactions & $73.2 \%$ & $23.8 \%$ & $3.9 \%$ \\
\cline { 2 - 5 } & International transactions & $80.5 \%$ & $18.3 \%$ & $1.2 \%$ \\
\hline \multirow{2}{*}{ Hungary } & Domestic transactions & $71.7 \%$ & $24.2 \%$ & $4.1 \%$ \\
\cline { 2 - 5 } & International transactions & $87.0 \%$ & $11.4 \%$ & $1.7 \%$ \\
\hline \multirow{2}{*}{ Eastern Europe } & Domestic transactions & $76.9 \%$ & $19.0 \%$ & $4.1 \%$ \\
\cline { 2 - 5 } & International transactions & $79.8 \%$ & $16.1 \%$ & $4.1 \%$ \\
\cline { 2 - 5 } & International transactions & $\mathbf{7 3 . 5 \%}$ & $\mathbf{2 2 . 1 \%}$ & $\mathbf{4 . 4 \%}$ \\
\hline \multirow{2}{*}{ Western Europe } & Domestic transactions & $\mathbf{7 7 . 9 \%}$ & $\mathbf{1 8 . 5 \%}$ & $\mathbf{3 . 6 \%}$ \\
\cline { 2 - 5 } & International transactions & $\mathbf{6 9 . 5 \%}$ & $\mathbf{2 5 . 7 \%}$ & $\mathbf{6 . 0 \%}$ \\
\hline
\end{tabular}

It is also necessary to pay attention to delayed payments that are becoming commonplace these days (Table 2). It is estimated that in Europe $1 / 3$ of the values of the invoices for both domestic and international transactions are overdue payments and the actual time of receiving the payment in 2011 for Europe was 52 days

The approval of any trade credit is a risk of a delayed payment or no payment at all. As a result, the intensification of the 'chain of delayed payments' may turn out to be a peril for the entire economy. A survey by Atradius in 2012 indicated that in the Eastern Europe 2.6\% of the value of receivables generated in the transactions realised on a domestic market were bad debts ${ }^{16}$. In the international transactions, this average was $1.8 \%$. The highest percentage of bad debts was unfortunately recorded in Poland, where $4.4 \%$ of the value of the domestic receivables could be deemed irrecoverable. For the international transactions, it was not much lower and amounted to $4.1 \%$. The best result was recorded for Hungary where as little as $1.7 \%$ of the domestic and $0.6 \%$ of the international receivables were deemed irrecoverable.

\footnotetext{
${ }^{16}$ Por. Payment Practices Barometer. Survey of Payment Behaviour of Central and Eastern Europe, Atradius, May 2008 and Payment Practices Barometer. Survey of Payment Behaviour of European Companies, Atradius, Winter 2008/2009.
}

Very often, a failure to pay on time is not the exclusive responsibility of the debtor, who actually got into trouble because of his suppliers failing to satisfy their debts. Payment backlogs and their negative consequences for the safety of the economic activity in particular were also noticed by the respondents. Over $30 \%$ of the entities from the Płock subregion perceived these backlogs as one of the main reasons for bad economic situation.

This was confirmed by the group of entities participating in the survey carried out periodically by NBP (National Bank of Poland) indicating an intensification of this phenomenon in the Polish economy. The evaluation of the bad situation of the recipients as an obstacle in the economic development, conducted since 2004, in both the value of the respondents' indications and the changing trends was convergent with the values recorded for payment backlogs ${ }^{17}$. Until the end of 2005 in the study on the obstacles the problem of payment backlogs and recovery of debts and the problem maintaining financial liquidity were distinguished as separate. From the first quarter of 2006, however these were joined for a single evaluation. Characteristic was also certain cyclicity in the consequences of the payment backlogs.

\footnotetext{
${ }^{17}$ Preliminary information on the condition of enterprises with particular attention focused on the economic situation, NBP, 2004-2011
} 


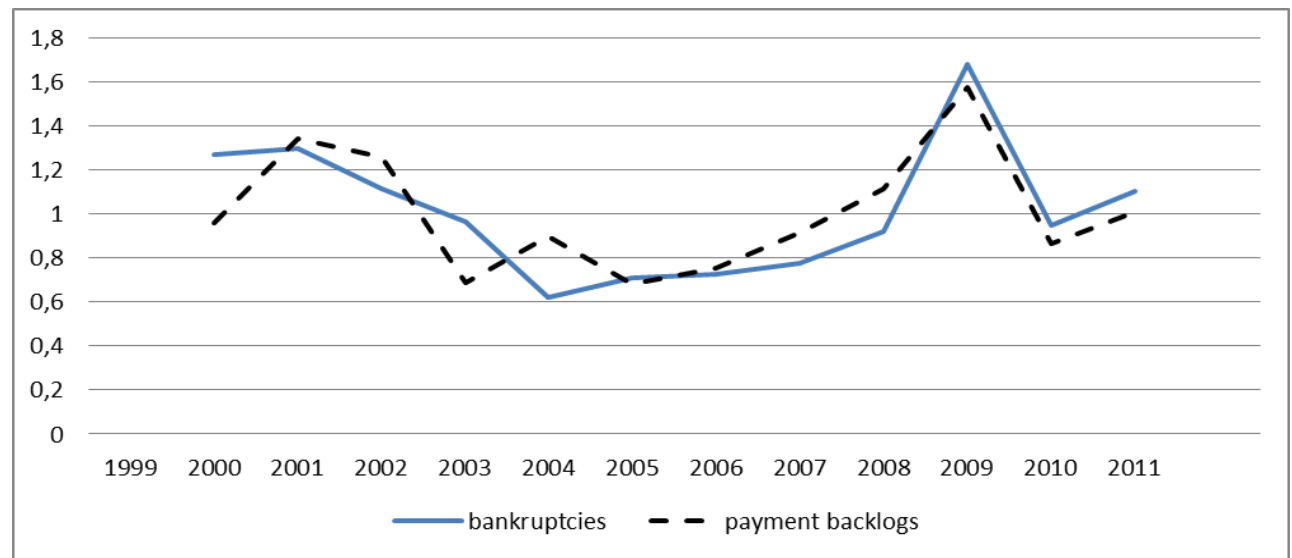

Graph 5. Dynamics of the phenomenon of payment backlogs and the number of bankruptcies in Poland (source: Own studies based on NBP (National Bank of Poland) data on the scale of the phenomenon of payment backlogs and Coface reports on the number of bankruptcies in Poland)

The related phenomena of payment backlogs and the number of bankruptcies have been shown in Graph 5.

Currently, an increase in the significance of payment backlogs is observed. The problem of untimely payments and their consequences for the economic activity of enterprises was most prominent in the second quarter of 2002 when this index reached a peak value of $20.1 \%$ of the respondents' indications. Starting from the subsequent quarter and for the entire following year the problems with debt recovery and related payment backlogs were on the second position among the obstacles in the development of business activity, as indicated by the respondents. It is noteworthy that the problem of payment backlogs is not only the consequence of the economic crisis but it has been in the Polish economy for quite a long time.

Already in 2001 Arkadiusz Protas, member of the Board of Business Center Club said: 'payment backlogs contribute to the bankruptcies of approximately 200.000 business per annum in our country ${ }^{18}$. Then, it was estimated that $30 \%-50 \%$ of the manufacturers have to wait for the payment from three to six months and it did happen that entities only succeeded in settling their accounts in excess of this period ${ }^{19}$.

Payment backlogs have been an issue in the economy for a long time. The crisis only contributed to the intensification of this problem. The main reason for the occurrence of this phenomenon is the deterioration of the payment morality of business entities and too expansive policies towards the clients such as extend-

18 Tomaszewski K. - Zatory szkodza firmom [in] Prawo i Gospodarka, 9.08.2001.

${ }^{19}$ Ibidem ing of the due dates. This would be nothing wrong if this was accompanied by longer times for paying the entity's own liabilities. Otherwise, a risk of deteriorated financial liquidity may occur leading to a domino effect and financial loop ${ }^{20}$. The situation was confirmed by the growth of the demand for debt recovery services.

\section{$5 \quad$ Price discounts in the control of receivables}

Keeping financial liquidity on the required level includes actions related to the approval of trade credits, credit risk assessment, proper security and management of receivables. The last stage in the circulation of money in an enterprise is the conversion of receivables into $\operatorname{cash}^{21}$.

From the point of view of financial liquidity, receivables are frozen assets and the aim of the management of receivables should be minimisation of their level and increasing the probability of their collection ${ }^{22}$. Companies develop different systems of influencing the level of receivables. One of them is the policy of price discounts in order to accelerate the payment of receivables, thus reducing the cycle conversion into cash (Graph 6).

\footnotetext{
${ }^{20}$ Tokarski M. - Faktoring $w$ matych $i$ średnich przedsiębiorstwach. Oficyna Ekonomiczna, Kraków 2005, p. 106.

${ }^{21}$ Sierpińska M., Tomala P. - Metody przyspieszenia sptywu należności do przedsiębiorstwa [in] Metody zarządzania finansami we współczesnych przedsiębiorstwach (red. P. Szczepankowski). WSFiZ, Warszawa 2004, p. 291.

${ }^{22}$ Golawska-Witkowska G., Rzeczycka A. - Zarzq̨dzanie należnościami w gospodarce rynkowe [in] Współczesne finanse. Stan i perspektywy rozwoju finansów przedsiębiorstw i ubezpieczeń (red. B. Kołosowska), UMK, Toruń 2008, p. 109.
} 


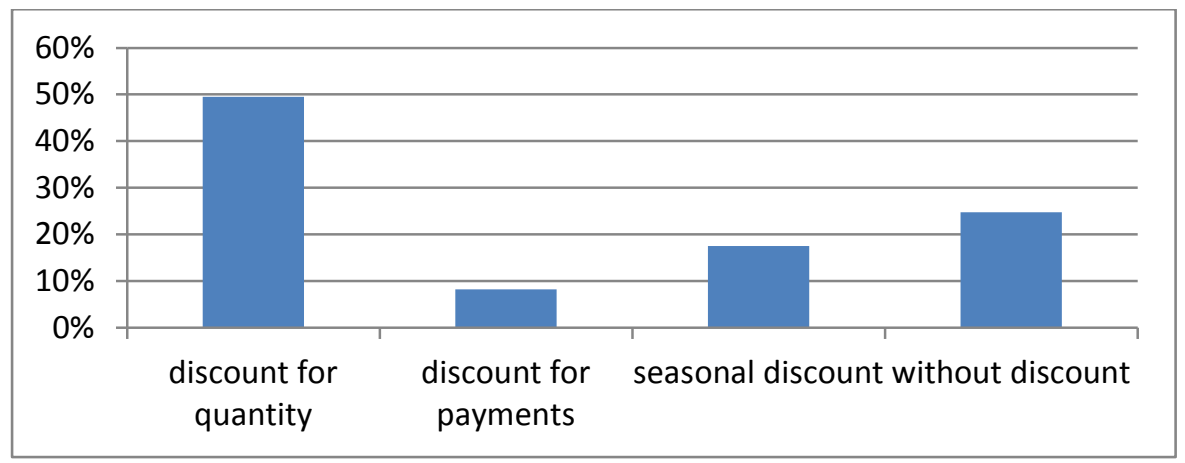

Graph 6. Types of price discounts provided by entities from the Płock subregion (source: based on own studies)

Polish dictionary defines the term 'discount' as a reduced price of a good or service granted by the seller to the buyer mainly when large purchases are made ${ }^{23}$. Following the above, this would relate only to a reduced price for a purchase of sufficiently large amount of goods or sufficiently high frequency of the purchases. A discount is tantamount to a discount, a price reduction. Yet, in other definitions, these terms are slightly distinguished. The term of price reduction has been confined to a reduced price resulting from a compensation for losses ${ }^{24}$. A discount has a wider meaning and denotes prices lower than the agreed ones for those who pay in cash, purchase in large amounts at a given frequency ${ }^{25}$.

A discount for large purchases denotes a reduced price for a given good or service granted to the buyer if a given purchase quota is realised. Hence, according to the definition of the Polish dictionary we can refer to it as a discount or a discount. A non-cumulative quota discount results from an initial price reduction because of a one-off purchase of a sufficient amount of goods. A cumulative quota discount denotes a price reduction of the initial price resulting from a sufficiently frequent purchases of given goods or services in a defined period.

In practise, the most frequently applied discounts are those related to the quantity or frequency of the purchases. They allow to tie the supplier to the client, reduce the risk of demand fluctuation in the case of cumulative discount and when non-cumulative discount is applied the price discount will result from the

\footnotetext{
${ }^{23}$ Szymczak M. - Stownik języka polskiego, t. 2, PWN, Warszawa 1988, p. 536.

${ }^{24}$ Szymczak M. Stownik..., op.cit., t. 1, p. 188.

${ }^{25}$ Szymczak M. - Stownik..., op.cit., t. 3, p. 5.
}

reduction of the costs of keeping the goods in stock, transport or packaging.

A seasonal discount applies in businesses characterised by their seasonality. The seller reduces the prices for the clients who will buy the goods or services in a low season. This reduces the costs of storage and secures the flow of cash in dead-seasons.

Functional discount reduces the prices for the middlemen for fulfilling certain functions and this extent depends on the extent of the costs that they assume.

From the point of view of the management of receivables the most significant seems the discount for "payment' given to those recipients who are willing to pay before the invoice due date specified in the contract. Such a description in the Polish dictionary corresponds to the term prompt payment discount defined as a price reduction for goods sold in installments or through a bank loan to a client paying in cash ahead of schedule. If the date of realisation of the cash discount is delayed by several days from the moment of the concluding of the transaction, we refer to it as discount for $\operatorname{cash}^{26}$.In the crisis, purchasing discounts in kind are getting increasingly prominent, consisting in maintaining the price level and offering an additional product without charge ${ }^{27}$. Their superiority is the possibility of maintaining the nominal prices for the client and a higher profit margin. These discounts have recently gained popularity in the homebuilding industry that feels the consequences of the crisis most.

\footnotetext{
${ }^{26}$ Bień W. - Zarządzanie finansami przedsiębiorstwa. Difin, Warszawa 2002, p. 174.

${ }^{27}$ Gorzeń W., Simon H, Zinoecker R. - 15 taktyk prowadzacych do szybkich wygranych [in] Harvard Business Review, Numer Specjalny - Zarządzanie w niepewnych czasach: skuteczne narzędzia i strategie, 2009, www.hbrp.pl (accessed on 12.06.2009).
} 
In the surveyed group of enterprises, the most popular were the discounts for large purchases, granted by half of the respondents. Tools that may have contributed to a faster collection of the money were of little popularity. Only $8 \%$ of the entities gave their contractors discounts for prompt payments. Most of the transactions were realised without security. It seems that in the situation when problems appear with timely payments, business entities should be interested in taking every action to encourage the contractors to pay as promptly as possible. We cannot be more wrong. Despite the fact that many entrepreneurs complained about the payment discipline of their contractors, they did not take any actions motivating the debtors to pay in time ${ }^{28}$.

Trade credit for most of the recipients is a flexible source of financing and its use usually does not incur any costs. However, if we want to get a cash discount, a profitability analysis is necessary. Trade credit is, in principle, a loan granted to the client and the extent of the cash discount corresponds to the interest rate. That is why every discount must be carefully analysed and calculated.

Giving any of the discounts must be economically justified i.e. measurable evidence of the advantage of benefits over the costs must be observed. In relation to discounts arising from the quantity or frequency of purchased products it is of vital importance to ascertain the optimum quantity of goods at which the total costs of sales is minimum and constitutes a basis for further price reduction. As far as discounts for prompt payment are concerned, the basis is the costs of the granted loan, counted as cash discount ${ }^{29}$.

\section{Selected tools for management of receivables}

Any credit, irrespective of its form, brings a risk of non-payment by an insolvent debtor. An obvious element accompanying the credit should be the application of tools that improve security against such risk.

There are many instruments for the management of receivables and their variety makes it easy for each entity to find a suitable one. The only requirement is the commitment to searching for an appropriate solution. Yet, despite a wide offer of solutions the range and method of their use by the companies is insuffi-

\footnotetext{
${ }^{28}$ Rostek K., Wiśniewski M., Kucharska A. - Cloud business intelligence for SMEs consortium [in] Foundations of Management, Vol. 04, No. 01(7), 2012.

${ }^{29}$ W. Bień - Zarzq̨zanie ..., op.cit., p. 174.
}

cient. For the majority of the entities this is still too complex and professional support is necessary from financial institutions offering specific solutions. Business entities, irrespective of the industry, choose the simplest solutions, which unfortunately translates into lower effectiveness. This problem is common in small and medium businesses that do not have sufficient knowledge and expertise in this matter.

Amicable debt recovery has become difficult these days. Very often, the lack of payment is not caused by the intention not to pay or even bad financial situation. The reason may as well be delayed payments by debtors of the party in default.

One of the ways to reduce the receivables and accelerate the flow of cash is the recipient's credit. In practise, it is advance payments and prepayments ${ }^{30}$. This means that the supplier receives the payment prior to manufacturing and delivering the goods. It can be granted free of charge or an additional cost of alternative financing may be included.

The results of the conducted survey have confirmed that despite a wide range of possibilities of using different tools for the management of receivables, the respondents do not use them efficiently.

The survey has shown that most of them applies only the most popular, simplest and cheapest solutions, but, consequently the least efficient.

The recipient's credit has been indicated by more than half of the respondents as a tool used at least 'frequently' (Graph 7). The tool of increasing popularity in Poland referred to as 'factoring' came rather low in the responses $-70 \%$ declared not to have ever used this tool. On the other hand, however, the policy of applying penalties to clients for late payments was not frequently applied. Over $60 \%$ of the respondents never charged penalty interest for overdue payments and only every fifth respondent decided to use this tool 'sometimes'. Similar was the situation regarding holding of the supplies to a recipient in default. $40 \%$ of the entities did not use this tool and only every fourth respondent deemed this as normal. Trouble in one business entity is a reason for further disturbances complicating the situation in the supply chain just like in the domino effect. Yet, despite delays in payments and the increasing level of overdue payments in the activity of the surveyed business entities there were no incentives for timely payments (discounts for prompt

${ }^{30}$ Sierpińska M., Wędzki D. - Zarządzanie ..., op. cit., p.192. 


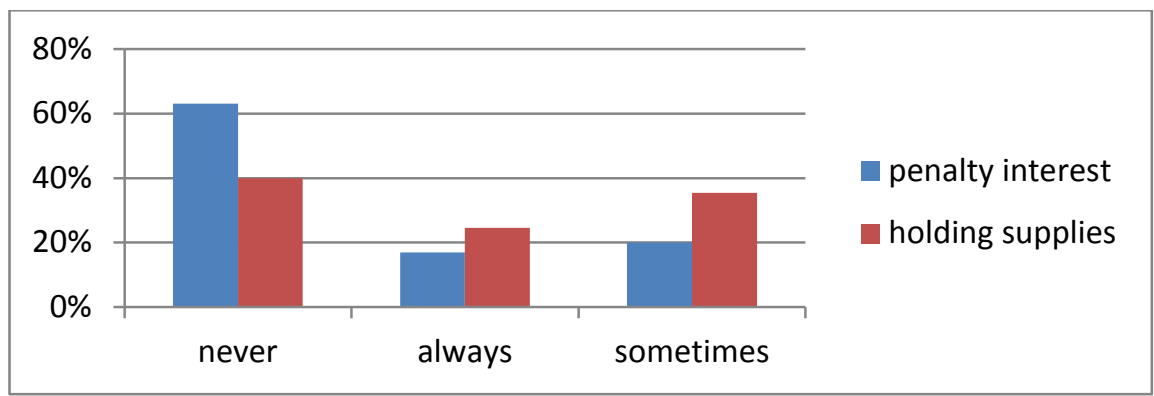

Graph 7 Penalty interest and holding supplies in the enterprises of the Płock subregion (source: based on own studies)

payment, penalty interest for overdue payments). Based on the above-presented surveys we may infer that the awareness of the managers of the enterprises as to the possibilities of use of tools for management of receivables was insufficient.

The surveys have confirmed a thesis that despite many possibilities created by the market in terms of management of receivables entrepreneurs do not use all legal means to penalise the partners in default. A business entity that is in default with payments should expect consequences such as creditor's surcharge for the use of his capital (interest). ${ }^{31}$ Such an approach should be of vital importance in the times of ever growing payment backlogs. This is, however, only theory. Incurring interest is a right not an obligation of the creditor and in practise few enterprises take this opportunity. On the other hand motivating partners to pay in time by applying cash discounts for prompt payments is not a frequent practise either ${ }^{32}$.

Good solutions for companies that have problems with timely payments are barter transactions. A barter contract allows exchanging goods for goods and services for services, goods for services and vice versa. It assumes a mutual compensation of the liabilities but it is exclusively based on non-monetary exchange. In a case when part of the contract is settled through monetary medium and part through a barter transaction we have a compensation contract $^{33}$.

\footnotetext{
${ }^{31}$ Hajkiewicz-Górecka M. - Conceptions for Financing a Universal, Open, Repository Hosting and Communication Platform for Web-Based Knowledge Resources [in] Foundations of Management, Vol. 04, No. 02(8), 2012.

${ }^{32}$ Ludynia A. - Smart grids in the process of building a competitive economy and energy security in Europe [in] Foundations of Management, Vol. 04, No. 02(8), 2012.

${ }^{33}$ Krupa T., Ostrowska T. Decision-Making In Flat And Hierarchical Decision Problems [in] Foundations of Management Vol. 04, No. 02(8), 2012.
}

Management of receivables is a process tightly related to the idea of securing the continuation of the company activity and maintaining its financial liquidity. This pertains to all entities irrespective of their size or specific industry. This process should entail clear rules and conditions of sale (coherent with the business entity main objective) that will constitute an important component of the policy of trade credit approval.

Management of receivables is not only the control of the timely payments, debt recovery in case of overdue payments, disciplining the debtors but also very often underestimated proactive behaviour. Its aim should be determining of the risk level related to a given transaction already on the stage preceding the signing of a contract and then, depending on the results of the assessment, differentiating the trade conditions. In order to minimise loss, an important activity in the process of management of receivables should be the adaptation of preventive actions to the previously assessed risk level.

\section{Conclusions}

Maintaining financial liquidity is a necessary condition for the continuation of economic operations. In the time of crisis when predicting future economic situation and future solvency is difficult, the care for financial liquidity becomes extremely important.

It is noteworthy that an important factor in the attempt to increase the interest in individual tools for management of receivables is educating the entrepreneurs and boosting their awareness of the existence of financial instruments, which directly translates into the ability to use them. Actions aiming at dissemination and spanning of knowledge of the entrepreneurs and company management on the available tools for security of transactions with deferred payments are one of the most desirable changes to improve the activity in this 
area. In this respect, a vital role is played by financial institutions. The planned changes should first include adapting their offer to the specificity, needs and expectations of the entrepreneurs seeking effective solutions in the management of receivables.

\section{$8 \quad$ References}

[1] Bień W. - Problemy efektywnej sprzedaży na kre$d y t$ [in] Zarządzanie majątkiem obrotowym w przedsiębiorstwie (red. J. Grzywacz), SGH, Warszawa 2006.

[2] Bień W. - Zarzqdzanie finansami przedsiębiorstwa. Difin, Warszawa 2002.

[3] Bilansowe wyniki finansowe podmiotów gospodarczych. GUS, 2006-2011.

[4] Fandrejewska A., Krześniak M. - Jak rozruszać kredyty. Rzeczpospolita, 1.07.2009.

[5] Gierszewska G., Romanowska M. - Analiza strategiczna przedsiębiorstwa. PWE, Warszawa 2009.

[6] Golawska-Witkowska G., Rzeczycka A. - Zarzadzanie należnościami $w$ gospodarce rynkowej, [in] Współczesne finanse. Stan i perspektywy rozwoju finansów przedsiębiorstw i ubezpieczeń, (red. B. Kołosowska), UMK, Toruń 2008.

[7] Gorzeń W., Simon H., Zinoecker R. - 15 taktyk prowadzacych do szybkich wygranych [in] Harvard Business Review. Numer Specjalny: Zarządzanie w niepewnych czasach: skuteczne narzędzia i strategie, 2009, www.hbrp.pl (accessed on 12.06.2009.

[8] Hajkiewicz-Górecka M. - Conceptions for Financing a Universal, Open, Repository Hosting and Communication Platform for Web-Based Knowledge Resources [in] Foundations of Management, Vol. 04, No. 02(8), 2012.

[9] Kreczmańska-Gigol K. - Windykacja należności. Difin, Warszawa 2011.

[10] Krupa T. Ostrowska T. - Decision-Making In Flat And Hierarchical Decision Problems [in] Foundations of Management, Vol. 04, No. 02(8), 2012.

[11] Ludynia A. - Smart grids in the process of building a competitive economy and energy security in Europe [in] Foundations of Management, Vol. 04, No 02(8), 2012.

[12] Marzec J., Pawłowska M. - Substytucja między kredytem kupieckim i bankowym w polskich przedsiębiorstwach. Bank i Kredyt, 43(6), 2012.

[13] Payment Practices Barometr, Atradius, June 2012.
[14] Payment Practices Barometer. Survey of Payment Behaviour of Central and Eastern Europe, Atradius, May 2008.

[15] Payment Practices Barometer. Survey of Payment Behaviour of European Companies. Atradius, Winter 2008/2009.

[16] Petersen M., Rajan R. - deTrade credit, theories and evidence [in] Review of financial Studies, 10(3), 1997.

[17] Raport BIG - Wskaźnik Bezpieczeństwa Obrotu Gospodarczego. BIG InfomMonitor, Warszawa, wrzesień 2013.

[18] Rostek K., Wiśniewski M., Kucharska A. - Cloud business intelligence for SMEs consortium [in] Foundations of Management, Vol. 04, No. 01(7), 2012.

[19] Rzeszutek E. - Holding groups: a safe corporate structure at the time of recession [in] Foundations of Management, Vol. 04, No. 02(8), 2012.

[20] Seretny M., Seretny A. - Sustainable marketing a new era in the responsible marketing development [in] Foundations of Management, Volume 04, No. 02(8), 2012.

[21] Sierpińska M., Tomala P. - Metody przyspieszenia spływu należności do przedsiębiorstwa [in] Metody zarządzania finansami we współczesnych przedsiębiorstwach (red. P. Szczepankowski). WSFiZ, Warszawa 2004.

[22] Sierpińska M., Wędzki D. - Zarzqdzanie ptynnościa finansowq $w$ przedsiębiorstwie. PWN, Warszawa 2005.

[23] Szymczak M. - Słownik języka polskiego, t. 2, PWN, Warszawa 1988.

[24] Tokarski M. - Faktoring $w$ matych i średnich przedsiębiorstwach. Oficyna Ekonomiczna, Kraków 2005.

[25] Tomaszewski K. - Zatory szkodza firmom [in] Prawo i Gospodarka, 9.08.2001.

[26] Wasilewski W. - A Total Risk Assessment in an Enterprise [in] Foundations of Management, Vol. 04, No. 02(8), 2012.

[27] Waśniewski T., Skoczylas W. - Teoria i praktyka analizy finansowej $w$ przedsiębiorstwie [in] Fundacja Rozwoju Rachunkowości w Polsce, Warszawa 2002.

[28] Wstępna informacja o kondycji sektora przedsiębiorstw ze szczególnym uwzględnieniem stanu koniunktury, NBP, 2004-2011. 